\title{
Author Correction: The global volume and distribution of modern groundwater
}

\author{
Tom Gleeson, Kevin M. Befus, Scott Jasechko, Elco Luijendijk and M. Bayani Cardenas
}

Correction to: Nature Geoscience https://doi.org/10.1038/ngeo2590, published online 16 November 2015.

In the version of this Article originally published, the wrong article was listed as ref. 33; it should have been "Oki, T. \& Kanae, S. Global hydrological cycles and world water resources. Science 313, 1068-1072 (2006).” This has been corrected in the online versions of the Article.

\section{Author Correction: A global analysis of terrestrial plant litter dynamics in non-perennial waterways}

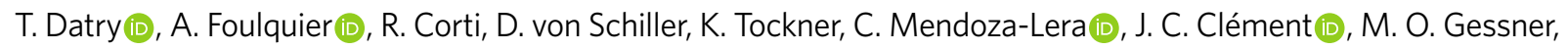
M. Moleón (1), R. Stubbington, B. Gücker, R. Albariño, D. C. Allen, F. Altermatt, M. I. Arce, S. Arnon, D. Banas,

A. Banegas-Medina, E. Beller, M. L. Blanchette, J. F. Blanco-Libreros, J. J. Blessing, I. G. Boëchat, K. S. Boersma, M. T. Bogan, N. Bonada, N. R. Bond, K. C. Brintrup Barría, A. Bruder, R. M. Burrows, T. Cancellario, C. Canhoto, S. M. Carlson (D), S. Cauvy-Fraunié, N. Cid, M. Danger, Bianca de Freitas Terra, A. M De Girolamo, Evans de La Barra, R. del Campo, V. D. Diaz-Villanueva, F. Dyer, A. Elosegi, E. Faye, C. Febria (1), B. Four, S. Gafny, S. D. Ghate, R. Gómez, L. Gómez-Gener, M. A. S. Graça, S. Guareschi, F. Hoppeler, J. L. Hwan, J. I. Jones, S. Kubheka, A. Laini, S. D. Langhans, C. Leigh, C. J. Little, S. Lorenz, J. C. Marshall, E. Martín, A. R. Mclntosh, E. I. Meyer, M. Miliša, M. C. Mlambo, M. Morais, N. Moya, P. M. Negus, D. K. Niyogi, A. Papatheodoulou, I. Pardo, P. Pařil, S. U. Pauls, V. Pešić, M. Polášek, C. T. Robinson, P. Rodríguez-Lozano, R. J. Rolls, M. M. Sánchez-Montoya, A. Savić, O. Shumilova, K. R. Sridhar, A. L. Steward, R. Storey, A. Taleb, A. Uzan, Ross Vander Vorste, N. J. Waltham, C. Woelfle-Erskine, D. Zak, C. Zarfl and A. Zoppini

Correction to: Nature Geoscience https://doi.org/10.1038/s41561-018-0134-4, published online 21 May 2018.

In the version of this Article originally published, the affiliation for M. I. Arce was incorrect; it should have been: ${ }^{5}$ Leibniz Institute of Freshwater Ecology and Inland Fisheries (IGB), Berlin, Germany. This has now been corrected in the online versions of the Article.

\section{Author Correction: Reduced air-sea $\mathrm{CO}_{2}$ exchange in the Atlantic Ocean due to biological surfactants}

Ryan Pereira, Ian Ashton, Bita Sabbaghzadeh, Jamie D. Shutler and Robert C. Upstill-Goddard

Correction to: Nature Geoscience https://doi.org/10.1038/s41561-018-0136-2, published online 28 May 2018.

In the version of this Article originally published, in the 'Acknowledgements' section the authors neglected to include the following text: "The Surface Ocean $\mathrm{CO}_{2}$ Atlas (SOCAT) is an international effort, endorsed by the International Ocean Carbon Coordination Project (IOCCP), the Surface Ocean Lower Atmosphere Study (SOLAS) and the Integrated Marine Biosphere Research (IMBeR) programme, to deliver a uniformly quality-controlled surface ocean $\mathrm{CO}_{2}$ database. The many researchers and funding agencies responsible for the collection of data and quality control are thanked for their contributions to SOCAT." This has now been added in the online versions of the Article. 